\title{
INDONESIA PUBLIC BANKS PERFORMANCE EVALUATION USING FUZZY LOGIC
}

\author{
Sugiarto \\ STIE Wiyatamandala, Department of Management, Indonesia \\ Tumpal Pandiangan \\ Matana University, Department of Informatics Engineering, Indonesia.
}

\begin{abstract}
Return on Asset (ROA) is a variable that has the greatest ability in predicting public banks stock prices in Indonesia. The coefficient of determination of ROA on public banks stock prices in Indonesia reached $54.8 \%$. ROA has a significant positive influence on public bank stock prices in Indonesia. Fuzzy logic process on the performance of the 15 public banks in Indonesia have been carried out using the data of ROA for the period 2010 up to 2013. Bank reference performance according to ROA is based on Bank Indonesia Letter No. 6/ 23DPNP /2011. The performance of each bank was analyzed by conventional methods and as a comparison used fuzzy logic. The evaluation with fuzzy logic method able to provide added value to the currently enforced performance evaluation method. There is significant difference in conclusion between the determination of fuzzy logic models and conventional method.
\end{abstract}

Keywords: ROA, Conventional methods, Fuzzy logic

\section{Introduction}

As one of financial indicators of the profitability of bank, Return on Asset (ROA) is a variable that has the greatest ability in predicting public banks stock prices in Indonesia. The coefficient of determination of ROA on Indonesia public banks stock prices in Indonesia reached $54.8 \%$. ROA influence significant positive on pub- lic banks stock prices in Indonesia [Sugiarto \& Nursiana, Adinoto, 2014].

Significance of ROA in public banks stock prices in Indonesia indicates that investors pay attention to the prospects of the bank according to the bank 's ability to empower the assets. ROA indicate the level of enterprise management capabilities to manage the entire company property or funds entrusted to them.

Korespondensi dengan Penulis:

Sugiarto, Tumpal Pandiangan:

Email: prof.sugiarto@gmail.com,tumpal_pandiangan@yahoo.com 
Fuzzy logic method which was introduced by Lotfi Zadh [1965], offered as a soft computing partnership in computing concept with words. In addition, the method can also support computational techniques to deal with inaccuracies and information that is granularity. Fuzzy theory provides a mechanism in the representation of linguistic construction like a little, a lot, a lot of, etc. In general, the fuzzy logic provides an inference structure that enables human reasoning. Although the fuzzy logic has been predicted its application in various fields [Altrock, 1995], the application of fuzzy logic in the evaluation of bank's financial performance is new.

In this study, fuzzy logic inference systems was used in the assessment of public banks performance in Indonesia for the period 2010 up to 2013. Bank reference performance according to ROA is based on Bank Indonesia (BI) Letter No. 6 / 23DPNP / 2011. In general, using conventional valuation method, public banks with ROA which are included in the category of very healthy have high stock price. With fuzzy logic it is tried to obtain public banks when using the conventional method are classified in the category of healthy or less than healthy but when using fuzzy logic are classified into the category of very healthy. The stock price of public banks who fall into that category, will not be as high as the price of public banks' stocks who fall into the category of very healthy ROA. Thus investors will get benefit if they can invest in such banks' stocks.

\section{Methodology}

\subsection{Research object}

The object of this research is the value of ROA of 15 public banks in Indonesia during the period 2010 to 2013. Prior to analysis using conventional methods and fuzzy logic it was already done corrections to the extreme value of ROA of 15 public banks in Indonesia.

\subsection{The research objective}

The research objective were to answer the following questions: (i) Does the evaluation with fuzzy logic method able to provide added value to the currently enforced performance evaluation method (ii) Is there any difference in conclusion between the determination of fuzzy logic models with conventional method?

\subsubsection{Fuzzy Logic}

The set of fuzzy logic was introduced as a mathematical tool for representing the linguistic obscurity. Fuzzy logic is based on fuzzy set theory as an extension of classical set theory in which the elements have different levels of membership. Sometimes in describing the logic, human reasoning which is based on two values of truth that is right and wrong is inadequate. Fuzzy logic uses the entire interval between 0 (false) and 1 (true) to depict human reason. Fuzzy system is an appropriate way to map an input space into an output space.

\subsection{Performance Evaluation with Fuzzy Logic}

According to the application of Fuzzy Logic, in general, there are three stages of the process, namely:

1. Fuzzifications is a process of mapping function input fuzzy membership value. A membership function is a curve that defines how each point in the input space is mapped to the membership value between 0 and 1 . There are various forms of membership functions, namely: triangular, trapezoidal, piecewise, Gaussian, bell-shaped, etc.

2. Inference is done with an associated rule ifthen which is associated with multiple input and output variables. Consider the rules are based on the description of words which is not mathematical definition, every relationship 
that can be explained by linguistic terms can also be defined by fuzzy logic. This means that the nonlinear system can also be explained and easily controlled with fuzzy logic.

3. Defuzzification is a variable conversion value output to the scrips value that can actually be used. This was done after evaluating feedback and applying it to the base rules. Centroid calculation method generally used for defuzzification.

There are two input variables to the fuzzy logic system, that are the ROA average results of the first two years ROA and the second two years ROA. Defuzzification results become an output variable that represents the value of public banks performance according to ROA based on fuzzy logic (Figure 1)

The process of fuzzy logic to the ROA value of each Bank has been done by entering the input variables and membership functions of fuzzy sets. The performance of each bank were analyzed by conventional methods and fuzzy logic with conditions as follows:

Calculating the average value of ROA for the first 2 years and the average ROA for the second 2 years, then made two types of performance evaluation, namely: (i) with the conventional method of calculating the average value of the results are stored in the attribute Average (ii) the method fuzzy logic results are stored in the attribute FL.

In the process of fuzzy logic, there are two input variables and one output variable. Each input variable has three Triangle membership functions (Table 1). This membership function, have the same interval, so both Variable ROA has the same weight (Figure 2).

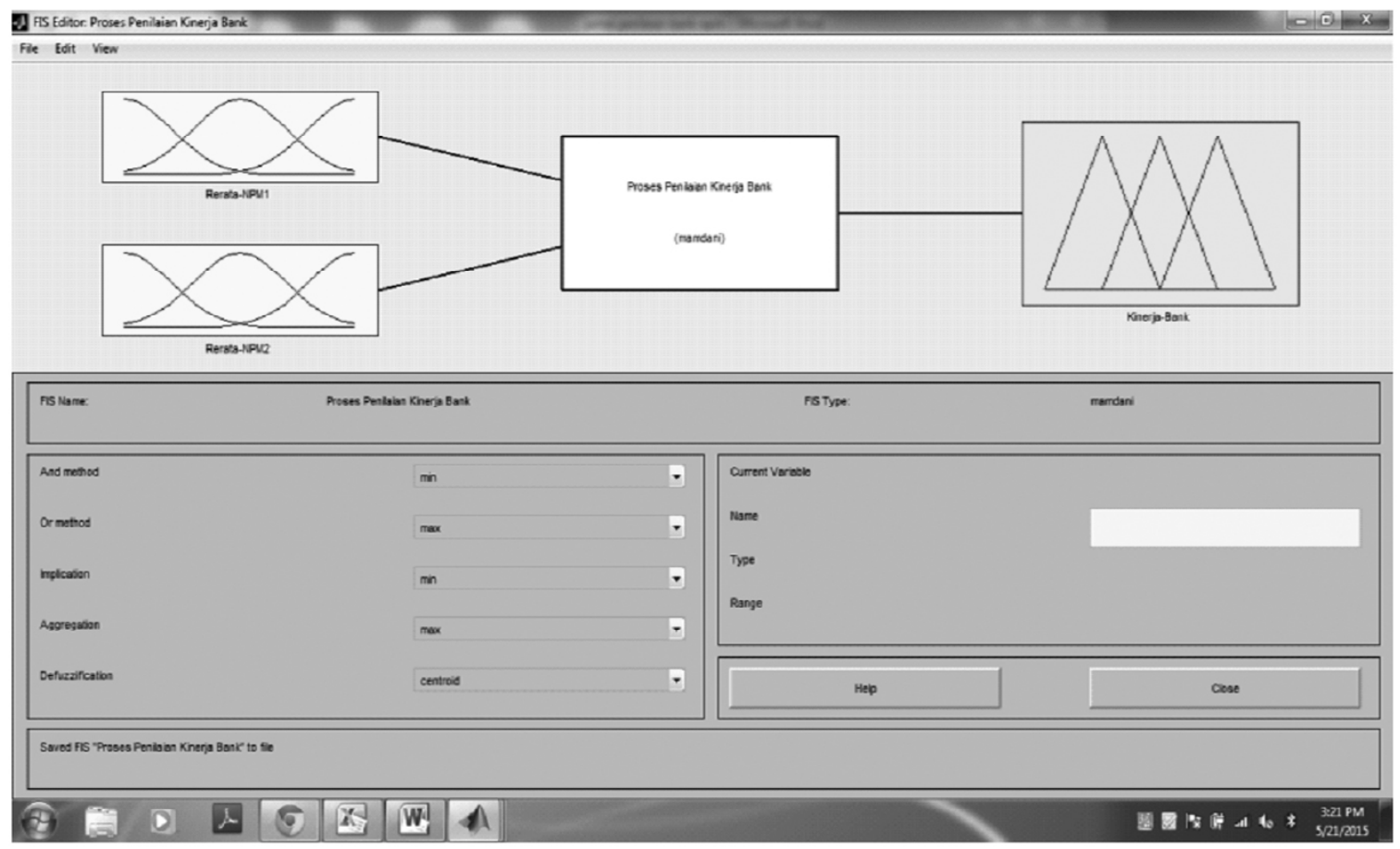

Figure 1: Determination of Banks performance using fuzzy logic 


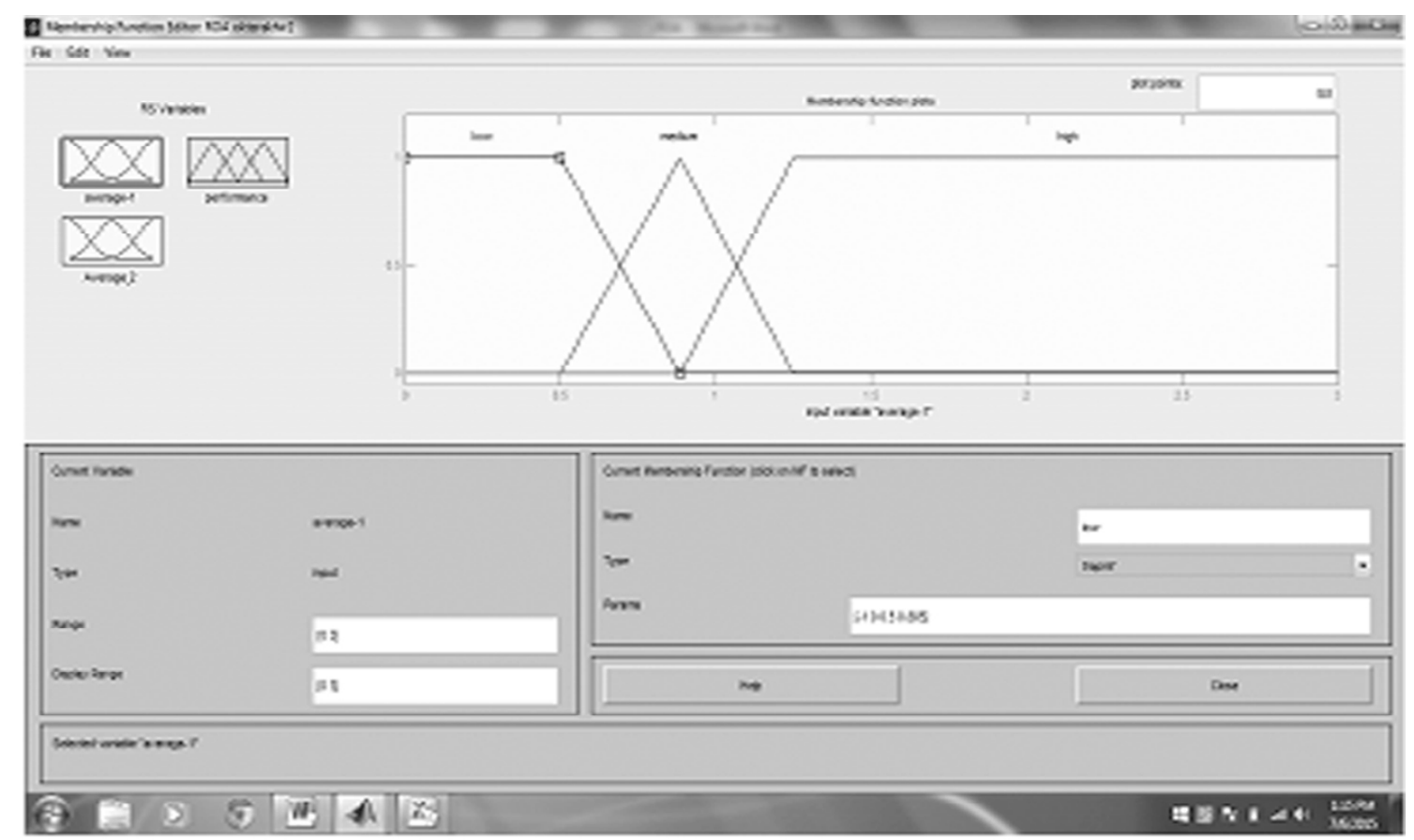

Figure 2: Membership function of $\mathrm{ROA}_{1}$ and $\mathrm{ROA}_{2}$

Table 1 Bank Health Ratings Criteria Based on The Ratio of the ROA

\begin{tabular}{|c|c|c|}
\hline Rating & Ratio of ROA [\%] & Performance \\
\hline 1 & ROA $>1.5$ & Very Healthy (V. Healthy) \\
\hline 2 & $1.25<\mathrm{ROA} \leq 1.5$ & Healthy \\
\hline 3 & $0.5<\mathrm{ROA} \leq 1.25$ & Quite Healthy (Q. Healthy) \\
\hline 4 & $0<\mathrm{ROA} \leq 0.5$ & Less Healthy (L. Healthy) \\
\hline 5 & ROA $\leq 0$ & Un Healthy (U. Healthy \\
\hline
\end{tabular}

Source: Assessment of bank health level codification (2014)

Table 2 Fuzzy Set of Input and Output Variable

\begin{tabular}{|c|c|c|c|c|}
\hline Function & Variable & Membership Function & Range & Domain \\
\hline \multirow{5}{*}{ Input } & \multirow{5}{*}{ ROA1 and ROA2 } & (Very Low) VL & \multirow{5}{*}[-0.5-1.75]{} & {$[-0.5-0.0]$} \\
\hline & & (Low) L & & {$[0.0-0.5]$} \\
\hline & & (Average) A & & {$[0.5-1.25]$} \\
\hline & & (High) H & & {$[1.25-1.5]$} \\
\hline & & (Very High) VH & & {$[1.5-1.75]$} \\
\hline \multirow{5}{*}{ Output } & \multirow{5}{*}{ Performance } & (Very Unsuccessful) VU & \multirow{5}{*}[-0.5-1.75]{} & {$[-0.5-0.0]$} \\
\hline & & (Unsuccessful) U & & {$[0.0-0.5]$} \\
\hline & & (Average) A & & {$[0.5-1.25]$} \\
\hline & & (Successful) S & & {$[1.25-1.5]$} \\
\hline & & (Very Successful) VS & & {$[1.5-1.75]$} \\
\hline
\end{tabular}




\section{Jurnal Keuangan dan Perbankan | PERBANKAN}

Vol. 20, No.2, Mei 2016: 334- 341

\subsection{Rules dan Inference}

Rule 'IF-THEN' as shown in figure 3 are used in determining the membership functions of input and output during the process of inference [Altrock, 1995], [Semerci, 2004].

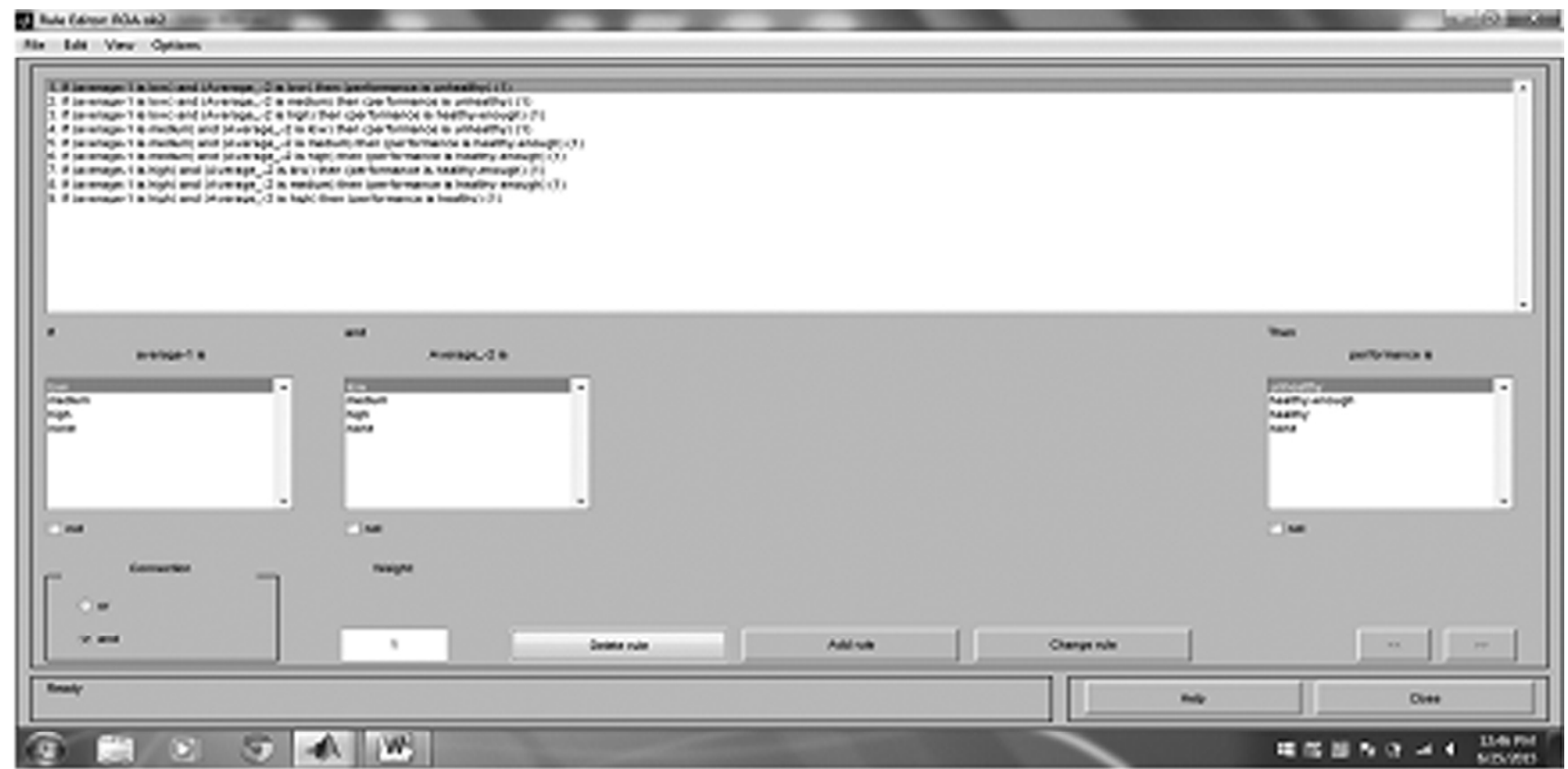

Figure 3: Editor rule of input $\mathrm{ROA}_{1}$ and $\mathrm{ROA}_{2}$

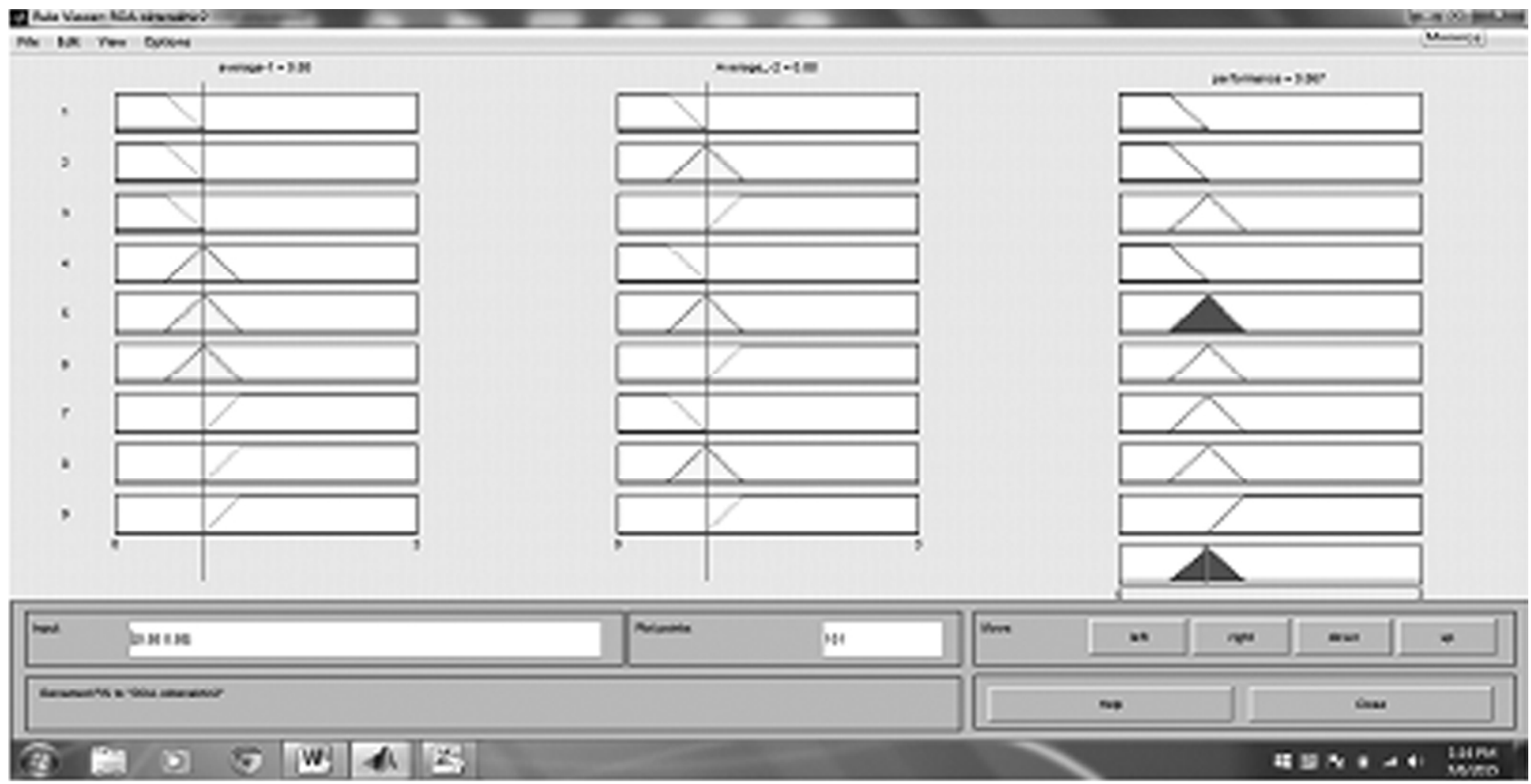

Figure 4: Active rules and performance value of ROA 
In one case, some rules are active for the same output membership function, in this case only one membership value is selected to proceed. This process is called 'Fuzzy Decision'. Some authors such as Mamdani, Takagi Surgeno and Zadeh, has built a range of techniques for fuzzy decision making and fuzzy inference [Shih-Ming Bai \& ShyiMing Chen, 2008]. This paper use the method proposed by Mamdani shown by equation (3) [Semerci, 2004; Zadeh, 1965; Rutkowski, 2004], as follows:

$$
\begin{aligned}
& \mu_{C}(y)=\frac{\max }{\mathrm{k}}\left[\operatorname { m i n } \left[\mu_{\mathrm{A}}(\operatorname{input}(\mathrm{i})) .\right.\right. \\
& \left.\left.\mu_{\mathrm{B}}(\operatorname{input}(j))\right]\right], k=1,2,3,4 \ldots .
\end{aligned}
$$

This expression is to determine the value of each rule output membership functions which are active. When a rule is active, an AND operation is applied between the input-output, the smallest input value is selected and the value of membership is determined as the value of the output mem- bership rules. This method is repeated so that the output membership functions defined for each rule. To sum entirely, AND operation (min) is graphically applied between the input and the OR operation (max) is applied between output.

\subsection{Determination of Performance Value}

Calculation of public bank's performance is done through a process of conversion of fuzzy numbers to the value of the Crips. This process is known as defuzzyfication. Many methods have been developed to process defuzzyfication. This paper applied Centroid technique which is one method widely applied to process defuzzyfication [Hyi-Ming Chen \& Ting Kuei Li, 2011]. Crips value are calculated from equation (4) below:

$z=\frac{\int \mu c(z) x Z x d z}{\int \mu c(z) x d z}$

\subsection{Fuzzy Logic Applications}

\begin{tabular}{|c|c|c|c|c|c|c|c|c|c|c|}
\hline $\begin{array}{c}\text { Name } \\
\text { (1) }\end{array}$ & $\begin{array}{c}2010 \\
(2)\end{array}$ & $\begin{array}{c}2011 \\
(3)\end{array}$ & $\begin{array}{c}2012 \\
(4)\end{array}$ & $\begin{array}{c}2013 \\
(5)\end{array}$ & $\begin{array}{c}\text { Average-1 } \\
\text { (6) }\end{array}$ & $\begin{array}{c}\text { Average-2 } \\
\text { (7) }\end{array}$ & $\begin{array}{c}\text { Average } \\
\text { (8) }\end{array}$ & $\begin{array}{l}\text { Conventional } \\
\text { Performance } \\
\text { (9) }\end{array}$ & $\begin{array}{l}\text { FL } \\
\text { (10) }\end{array}$ & $\begin{array}{c}\text { FL } \\
\text { Performance } \\
\text { (11) } \\
\end{array}$ \\
\hline BBCA & 2.61 & 2.83 & 2.65 & 2.87 & 2.72 & 2.76 & 2.74 & V.Healthy & 2.04 & V.Healthy \\
\hline BBKP & 1.04 & 1.3 & 1.28 & 1.07 & 1.17 & 1.175 & 1.1725 & Quite Healthy & 1.95 & V.Healthy \\
\hline BBNI & 1.65 & 1.94 & 2.11 & 2.34 & 1.795 & 2.225 & 2.01 & V.Healty & 2.04 & V.Healty \\
\hline BBRI & 2.84 & 3.21 & 3.39 & 3.41 & 3.025 & 3.4 & 3.2125 & V.Healty & 3.21 & V.Healty \\
\hline BBTN & 1.34 & 1.26 & 1.22 & 1.19 & 1.3 & 1.205 & 1.2525 & Healthy & 1.99 & V. Healthy \\
\hline BDMN & 2.52 & 2.43 & 2.64 & 2.26 & 2.475 & 2.45 & 2.4625 & V.Healthy & 2.04 & V.Healty \\
\hline BJBR & 2.05 & 1.77 & 1.68 & 1.94 & 1.91 & 1.81 & 1.86 & V.Healthy & 2.04 & V. Healthy \\
\hline BMRI & 2.08 & 2.3 & 2.52 & 2.57 & 2.19 & 2.545 & 2.3675 & V.Healthy & 2.04 & V.Healthy \\
\hline BNGA & 1.78 & 1.9 & 2.15 & 1.96 & 1.84 & 2.055 & 1.9475 & V.Healthy & 2.04 & V. Healthy \\
\hline BNII & 0.71 & 0.71 & 1.05 & 1.12 & 0.71 & 1.085 & 0.8975 & Quite Healthy & 0.599 & Quite Healthy \\
\hline BNLI & 1.36 & 1.14 & 1.04 & 1.04 & 1.25 & 1.04 & 1.145 & Quite Healthy & 1.75 & V.Healthy \\
\hline BTPN & 2.42 & 3 & 3.35 & 3.06 & 2.71 & 3.205 & 2.9575 & V. Healthy & 2.71 & V. Healthy \\
\hline MEGA & 1.84 & 1.73 & 2.11 & 0.79 & 1.785 & 1.45 & 1.6175 & V. Healthy & 2.04 & V.Healthy \\
\hline NISP & 0.72 & 1.26 & 1.16 & 1.17 & 0.99 & 1.165 & 1.0775 & Quite Healthy & 1.62 & V.Healthy \\
\hline PNBN & 1.3 & 1.82 & 1.53 & 1.26 & 1.56 & 1.395 & 1.4775 & Healthy & 2.04 & V.Healthy \\
\hline
\end{tabular}

Table 3 ROA $_{1}$ and ROA Value and Calculated Performance Value by Triangle Membership Function 
Performance analysis of the 15 public banks in Indonesia according to their ROA in the period 2010 up to 2013 were carried out by conventional methods and fuzzy logic. Performance analysis with the conventional method done by calculating the average of ROA in the 4-year period for each bank. Column 8 and column 9 of Table 3 shows the performance of each bank based on ROA over the last 4 years using conventional method. There were two banks in healthy category: namely BBTN and PNBN with consecutive average ROA variable 1.2525 and 1.4775 , and there were four banks in Quite Healthy category: namely BBKP, BNII, BNLI and NISP with consecutive average ROA variable $1.1725,0.8975,1.145$ and 1.0775. Other banks were in Very Healthy category. While the results of analysis by fuzzy logic are shown in column 10 and column 11 of Table 3. there was only one bank not in Very Healthy category, namely BNII, with the fuzzy logic value of ROA equal to 0.599 and other banks were included in the category of Very Healthy. Significant difference results of the using of conventional method and fuzzy logic are shown in Table 4 below.

Table 4 Significant Difference Results of the Using of Conventional Method and Fuzzy logic

\begin{tabular}{|c|c|c|c|c|}
\hline Name & Average & Conventional Performance & FL & FL Performance \\
\hline BBKP & 1.1725 & Quite Healthy & 1.95 & V.Healthy \\
\hline BBTN & 1.2525 & Healthy & 1.99 & V. Healthy \\
\hline BNLI & 1.145 & Quite Healthy & 1.75 & V.Healthy \\
\hline NISP & 1.0775 & Quite Healthy & 1.62 & V.Healthy \\
\hline PNBN & 1.4775 & Healthy & 2.04 & V.Healthy \\
\hline
\end{tabular}

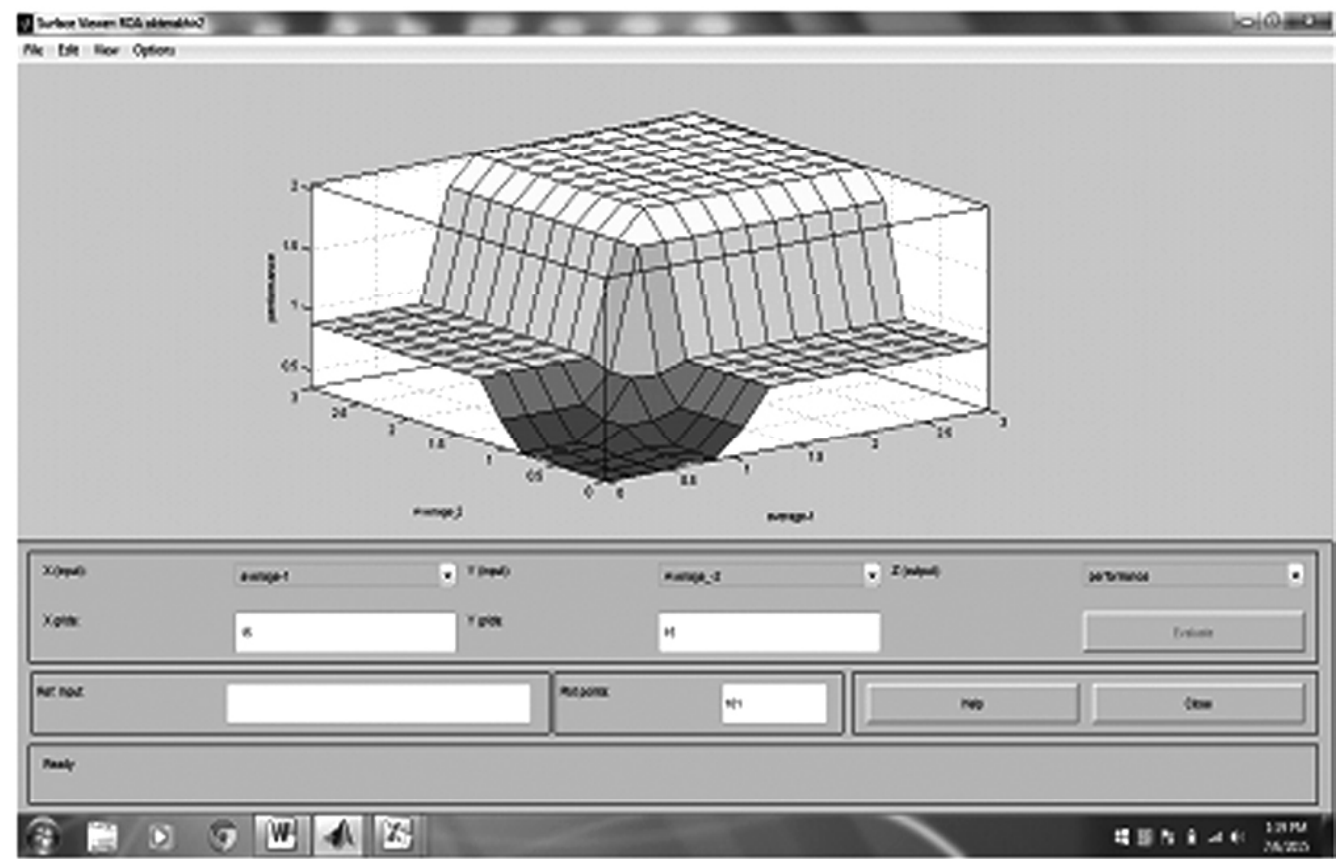

Figure 5: Three dimensional of surface viewer of rule base explains the average-1 (ROA1) in on $\mathrm{X}$-axis and the average- 2 (ROA2) in on $\mathrm{Y}$-axis with respective to performance on Z-axis 


\section{Conclusion}

The evaluation with fuzzy logic method able to provide added value to the currently enforced performance evaluation method. There is significant difference in conclusion between the determination of fuzzy logic models with conventional method. Investors are predicted would obtain benefit if they choose banks which are shown in Table 4 , as these banks actually have a very healthy ROA value but with conventional methods categorized under very healthy so that their stock prices are relatively cheaper.

\section{References}

Altrock, V., C (1995): “Fuzzy Logic Applications in Europe". IEEE Press. Chicago.

Berger, A. N. \& DeYoung, R (1997): "Problem loans and cost efficiency in commercial banks". Journal of Banks and Finance 21, 849-870.

Dhillon, Upinder, S \& Johnson, Herb (1994): “The effect of dividend changes on stock and bond prices". The Journal of Finance, 281-289.

Hayati, Kemala (2011): “Analisis Faktor-Faktor yang Mempengaruhi Perubahan Harga Saham dalam Keputusan Berinvestasi". Fakultas Ekonomi \& Manajemen Institut Pertanian Bogor. Bogor.

Hussain, Q. \& Wihlborg, C (1999): “Corporate insolvency procedures and bank behaviour: A study of selected Asian economies". IMF Working Paper, 144 .

Hyi-Ming Chen and Ting Kuei Li (2011): "Evaluating Students' Learning Achievement using Fuzzy Membership Functions and Fuzzy Rules". Expert System with Application, 38 4368-4381.
Pandey, I.M (2002): “Capital structure and market power interaction: evidence from Malaysia", in Zamri Ahmad, Ruhani Ali, Subramaniam Pillay. 2002. Proceedings for the fourth annual Malaysian Finance Association Symposium. $31^{\text {st }}$ May-1 $1^{\text {st }}$ June. Penang. Malaysia.

Rutkowski, L (2004): “Flexible Neuro-Fuzzy Systems: Structures, Learning and Performance Evaluation". Bostan: Kluwer Academic Publisher.

Semerci, Ç (2004): “The Influence Of Fuzzy Logic Theory On Students' Achievement". The Turkish Online Journal of Educational Technology, 3 (2), Article 9.

Shih-Ming Bai and Shyi-Ming Chen (2008): "Evaluating Students' Learning Achievement based on Fuzzy Rules with Fuzzy Reasoning Capability". Expert System with Application, 34 399-410.

Shruti S Jamsandekar and R.R Mudholkar (2013): “Performance Evaluation by Fuzzy Inference Technique". International Journal of Soft Computing and Engineering (IJSCE) ISSN: 2231-2307, Volume-3, Issue-2, May 2013

Sugiarto \& Nursiana, Adinoto (2014): “Peramalan Harga Saham Perusahaan Perbankan Tbk Atas Dasar Variabel-variabel Keuangan Utama Perusahaan". Jurnal Bina Manajemen. ISSN: 2303-0283.Volume II. Nomor 2. Maret 2014.

Woolridge, J. Randall (1983): “Dividend changes and security prices". The Journal of Finance, 1607-1615.

Zadeh, L.A (1965): “Information and Control. Fuzzy sets". Retrieved September 102009 from http://wwwbisc.cs.berkeley.edu/Zadeh-1965.pdf 
